\title{
MENYOAL KEKUATAN EKSEKUTORIAL PIDANA UANG PENGGANTI DALAM UNDANG UNDANG NOMOR 3 TAHUN 1971 TENTANG PEMBERANTASAN TINDAK PIDANA KORUPSI
}

\author{
Handoko Alfiantoro \\ Kejaksaan Negeri Situbondo \\ Jalan Basuki Rahmat 1A Situbondo 68322 \\ Universitas Abdurachman Saleh (UNARS) Situbondo \\ Jalan PB Sudirman Nomor 07 Situbondo 671191 \\ Email: handokoalfiantoro@yahoo.co.id/handokoalfiantoro@gmail.com
}

\begin{abstract}
An important instrument in law enforcement against corruption is the existence of an additional crime in the form of paying as much substitute money as same with corrupt money. However, it is still a problem with the law enforcement of criminal acts of corruption committed before the Law No.31/1999 concerning the Eradication of Corruption Crime was implemented. The Law No. 31/1999 which provided a clear solution to the steps of how if the penalty for substitute money was not paid was not contained in the RI Law No.3 of 1971. The opinion that if a corruption case excludes a judge made law, then it becomes possible if corruption cases in the past can still be prosecuted and tried in the present by using RI Law No.3 of 1971. This article use normative juridical research with a statute approach, comparative approach and conceptual approach, which aims to critically examine the executorial power of criminal substitute money in the Law No.3 of 1971 concerning the Eradication of Corruption Crimes
\end{abstract}

Keywords: Corruption, Substitute Criminal Money, Strength Executorial.

\begin{abstract}
ABSTRAK
Instrumen penting dalam law enforcement terhadap tindak pidana korupsi yaitu pidana tambahan berupa pembayaran sejumlah uang pengganti maksimal sama dengan uang yang telah dikorupsi. Namun masih menjadi persoalan terhadap penegakan hukum tindak pidana korupsi yang dilakukan sebelum Undang undang No.31 Tahun 1999 tentang Pemberantasan Tindak Pidana Korupsi diberlakukan. Ketentuan Undang undang No.31 Tahun 1999 memberikan jalan keluar secara tegas tentang upaya apabila hukuman uang pengganti tersebut tidak dibayar yang tidak diatur dalam Undang undang No.3 Tahun 1971. Adanya pendapat jika perkara korupsi mengenyampingkan masa daluwarsa (judge made law), sehingga memungkinkan jika perkara korupsi pada masa lalu masih dapat dituntut dan diadili pada masa sekarang dengan menggunakan Undang undang No.3 Tahun 1971. Artikel ini menggunakan metode penelitian yuridis normatif melalui pendekatan undang-undang, pendekatan perbandingan dan pendekatan konseptual yang bertujuan untuk mengkaji secara kritis kekuatan eksekutorial pidana uang pengganti dalam Undang undang No.3 Tahun 1971 tentang Pemberantasan Tindak Pidana Korupsi.
\end{abstract}

Kata Kunci: Korupsi, Pidana Uang Pengganti, Kekuatan Eksekutorial. 


\section{PENDAHULUAN}

Berawal dari pemikiran bahwa manusia merupakan serigala bagi manusia lain (homo homini lupus $)^{1}$ yang selalu mementingkan diri sendiri dan tidak mementingkan keperluan orang lain, maka diperlukan suatu aturan atau norma untuk mengaturnya. Keamanan dan ketertiban di dalam masyarakat akan tercipta dan terpelihara apabila tiap anggota masyarakat menaati peraturan (norma) yang ada dalam masyarakat itu sendiri, dan untuk ditaati diperlukan suatu sanksi bagi pelanggarnya. Adapun peraturan hidup kemasyarakatan yang bersifat mengatur dan memaksa untuk menjamin tata tertib masyarakat tersebut seringkali dinamakan dengan peraturan hukum.

Hukum merupakan peraturan mengenai tingkah laku manusia dalam pergaulan masyarakat yang diadakan oleh badan-badan resmi yang berwajib, yang bersifat memaksa, dan sanksi terhadap pelanggaran peraturan tersebut adalah tegas ${ }^{2}$. Adapun bagian dari keseluruhan hukum yang berlaku di suatu negara yang mengadakan dasar-dasar dan aturan untuk menentukan perbuatanperbuatan yang tidak boleh dilakukan/ dilarang dengan ancaman sanksi berupa pidana tertentu bagi yang melanggar aturan tersebut disebut Hukum Pidana ${ }^{3}$.
Manifestasi konkrit hukum pidana tersebut kemudian dituangkan di dalam peraturan perundang-undangan pidana. Lebih lanjut Moeljatno menyatakan bahwa perbuatan yang oleh hukum pidana dilarang dan diancam dengan pidana dinamakan perbuatan pidana ${ }^{4}$. Berdasarkan hal ini maka setiap orang yang melakukan perbuatan pidana akan dikenai sanksi berupa penjatuhan pidana tertentu seperti yang telah diatur dan diancamkan dalam Kitab Undang-Undang Hukum Pidana (KUHP) atau pun peraturan perundangundangan khusus di luar KUHP.

Tindak pidana korupsi merupakan salah satu perbuatan pidana yang diatur secara khusus di luar KUHP, tepatnya dalam undang-undang tentang pemberantasan tindak pidana korupsi yang telah beberapa kali mengalami penggantian dan perubahan. Mulai dari Undang undang Nomor 24 Prp. Tahun 1960, kemudian Undang undang Nomor 3 Tahun 1971 yang disahkan dan diundangkan tertanggal 29 Maret 1971 yang merupakan instrumen hukum pemberantasan tindak pidana korupsi dengan masa berlaku lebih dari 28 (dua puluh delapan) tahun. Selanjutnya diganti dengan Undang undang Nomor 31 Tahun 1999 yang disahkan dan diundangkan pada tanggal 16 Agustus 1999 yang kini diubah dengan Undang undang

1 Ditegaskan oleh Thomas Hobbes berdasarkan Teori Pembenaran Kekuasaan Negara melalui Teori Kekuatan Fisik berkenaan dengan Status Naturalis.

2 Kansil, CST., (1989), Pengantar Ilmu Hukum dan Tata Hukum Indonesia, Jakarta: Balai Pustaka, hlm.39.

3 Moeljatno, (2002), Asas Asas Hukum Pidana. Jakarta: Rineka Cipta. hlm.1.

4 Ibid., hlm.2. 
Nomor 20 Tahun 2001 tentang Perubahan Atas Undang undang Nomor 31 Tahun 1999 tentang Pemberantasan Tindak Pidana Korupsi yang resmi berlaku sejak tanggal 21 Nopember 2001.

Durasi waktu berlaku yang relatif lama membuat potensi mengadili pelaku tindak pidana korupsi menggunakan Undang undang Nomor 3 Tahun 1971 tentang Pemberantasan Tindak Pidana Korupsi sangat mungkin dilakukan. Telah diketahui bersama jika tindak pidana korupsi merupakan salah satu jenis kejahatan inkonvensional yang sangat berbahaya, karena dapat menyentuh berbagai kepentingan yang menyangkut hak asasi, ideologi, serta keuangan dan perekonomian negara yang sistematis dan sulit diberantas. Oleh karena itu tindak pidana korupsi telah disepakati menjadi kejahatan luar biasa (extra ordinary crimes) dan kejahatan serius (seriousness crimes), sehingga penanganan serta pemberantasannya harus dengan cara yang luar biasa dan serius juga.

Salah satu keseriusan pemberantasan tindak pidana korupsi sebenarnya telah diaplikasikan secara nyata dalam Undang undang Nomor 3 Tahun 1971 tentang Pemberantasan Tindak Pidana Korupsi, yaitu dengan memberlakukan pidana tambahan di luar ketentuan KUHP, yang salah satunya adalah hukuman membayar uang pengganti yang jumlahnya sebanyak-banyaknya sama dengan harta benda yang diperoleh dari korupsi sebagaimana diatur dalam Pasal 34 huruf c Undang undang Nomor 3 Tahun 1971 tentang Pemberantasan Tindak Pidana Korupsi. Hal ini tentunya merupakan terobosan hukum positif untuk mengganti kerugian keuangan negara yang telah ditimbulkan oleh para pelaku tindak pidana korupsi.

Namun demikian tidak adanya tahapan jalan keluar yang tegas dalam bunyi pasal tentang bagaimana apabila terpidana pelaku tindak pidana korupsi tidak membayar hukuman pidana pengganti dalam Undang undang Nomor 3 Tahun 1971 tentang Pemberantasan Tindak Pidana Korupsi membuat para penegak hukum cenderung kesulitan untuk mengaplikasikan dan mengeksekusi pemberlakuan pidana uang pengganti tersebut. Penegakan hukum terhadap tindak pidana korupsi yang menggunakan Undang undang Nomor 3 Tahun 1971 seringkali tidak mencantumkan diktum yang tegas dalam bentuk putusan pengadilan tentang bagaimana ketentuan apabila hukuman pidana pengganti tersebut tidak dibayarkan, sehingga membuat persoalan dalam kekuatan eksekutorialnya.

Hal tersebut tentunya sangat berbeda dengan ketentuan Undang undang Nomor 31 Tahun 1999 tentang Pemberantasan Tindak Pidana Korupsi, yang justru lebih tegas mengatur tentang tahapan bagaimana apabila terpidana pelaku tindak pidana korupsi tidak membayar hukuman pidana pengganti dalam bentuk bunyi pasal demi pasal, sehingga para 
penegak hukum menjadi lebih teliti dalam pencantuman isi putusan pengadilan yang dengan tegas membunyikan tentang tahapan jalan keluar terhadap hukuman pidana pengganti yang tidak dibayarkan.

Lebih lanjut dengan adanya pendapat jika perkara korupsi mengenyampingkan masa daluwarsa (judge made law), maka menjadi memungkinkan jika perkara korupsi pada masa lalu yang dilakukan sebelum Undang undang Nomor 31 Tahun 1999 tentang Pemberantasan Tindak Pidana Korupsi disahkan dan diundangkan, masih dapat disidangkan pada masa sekarang dan masa mendatang dengan menggunakan Undang undang Nomor 3 Tahun 1971 tentang Pemberantasan Tindak Pidana Korupsi, sehingga potensi problematika tentang kepastian jalan keluar pemberlakuan pidana tambahan berupa hukuman uang pengganti yang terpidananya tidak membayar masih dapat berkelanjutan di tengah gencarnya semangat penyelematan dan pemulihan keuangan negara. Hal ini yang membuat penulis tertarik untuk mengkaji lebih lanjut secara kritis tentang Kekuatan Eksekutorial Pidana Uang Pengganti dalam Undang undang Nomor 3 Tahun 1971 tentang Pemberantasan Tindak Pidana Korupsi.

Berdasarkan uraian di atas penulis mendapatkan beberapa pokok permasalahan antara lain Bagaimana kekuatan eksekutorial

putusan pengadilan yang tidak mencantumkan secara tegas jalan keluar terhadap pidana uang pengganti yang tidak dibayar dalam Undang undang Nomor 3 Tahun 1971 tentang Pemberantasan Tindak Pidana Korupsi? Bagaimana penerapan pidana uang pengganti dalam penegakan hukum pemberantasan tindak pidana korupsi yang menggunakan Undang undang Nomor 3 Tahun 1971 tentang Pemberantasan Tindak Pidana Korupsi pada masa mendatang?

Metode penelitian yang digunakan dalam tulisan ini menggunakan tipe penelitian yuridis normatif, dengan pendekatan masalah yang digunakan melalui pendekatan undangundang (statute approach), pendekatan perbandingan (comparative approach), dan pendekatan konseptual (conceptual approach $)^{5}$. Adapun sumber bahan hukum yang dipakai adalah sumber bahan hukum primair berupa peraturan perundangundangan terkait, bahan hukum sekunder berupa buku-buku tentang hukum, dan bahan non hukum berupa buku-buku diluar hukum ${ }^{6}$. Terkait dengan metode analisis bahan hukum yang digunakan dalam tulisan ini menggunakan metode deduktif, yaitu berpangkal dari prinsip-prinsip dasar kemudian menghadirkan objek yang hendak diteliti, dengan kata lain, berpangkal dari

\footnotetext{
5 Marzuki, P.M., (2008), Penelitian Hukum, Jakarta: Kencana Prenada Media Group, hlm.93.

$6 \quad$ Ibid, hlm.141-143.
} 
prinsip-prinsip umum menuju prinsip-prinsip khusus ${ }^{7}$.

\section{PEMBAHASAN}

Kekuatan Eksekutorial Putusan Pengadilan Yang Tidak Mencantumkan Secara Tegas Jalan Keluar Terhadap Pidana Uang Pengganti Yang Tidak dibayar Dalam Undang undang Nomor 3 Tahun 1971 tentang Pemberantasan Tindak Pidana Korupsi

Kata korupsi berasal dari bahasa latin yaitu Corruptie, yang berarti penyuapan, perusakan moral, perbuatan yang tidak beres dari jawatan, pemalsuan dan sebagainya. Korupsi juga bisa diartikan sebagai perbuatan yang buruk seperti penggelapan uang, penerimaan uang sogok, dan sebagainya ${ }^{8}$.

Harmein Hadiati Koeswadji menulis bahwa bila ditinjau dari segi istilah, korupsi berasal dari kata Corrupteia, yaitu yang dalam bahasa latin berarti bribery atau seduction, maka yang diartikan dengan corrupto dalam bahasa latin ialah corrupter atau seducer. Dari kata bribery tersebut kemudian dapat diartikan sebagai memberikan atau menyerahkan kepada seseorang untuk agar orang tadi berbuat untuk guna keuntungan (dari) pemberi ${ }^{9}$.
Secara umum berdasarkan ketentuan dalam Undang undang Nomor 31 Tahun 1999 tentang Pemberantasan Tindak pidana Korupsi sebagaimana telah diubah dengan Undang undang Nomor 20 Tahun 2001 tentang perubahan atas Undang undang Nomor 31 Tahun 1999 tentang Pemberantasan Tindak Pidana Korupsi, ada 7 (tujuh) kelompok tindak pidana korupsi, yaitu: ${ }^{10}$

1. Merugikan keuangan/perekonomian negara

2. Suap menyuap

3. Penggelapan dalam jabatan

4. Pemerasan

5. Perbuatan Curang

6. Benturan kepentingan dalam pengadaan

7. Gratifikasi

ditambah dengan 6 (enam) Tindak Pidana lain yang berkaitan dengan tindak pidana korupsi, yaitu:

1. Merintangi Proses pemeriksaan perkara korupsi

2. Tidak memberi keterangan/memberikan keterangan yang tidak benar

3. Bank yang tidak memberikan keterangan rekening tersangka

Ibid, hlm. 42.

8 Prakoso, D., (1986), Kejahatan-Kejahatan yang Merugikan dan Membahayakan Negara, Jakarta: Bina Aksara, hlm. 391.

9 Koeswadji, H.H., (1994), Korupsi di Indonesia Dari Delik Jabatan Ke Tindak Pidana Korupsi, Bandung: PT Citra Aditya Abadi, hlm. 32.

10 Komisi Pemberantasan Korupsi, (2006), Memahami Untuk Membasmi: Buku Panduan untuk Memahami Tindak Pidana Korupsi, Jakarta: Komisi Pemberantasan Korupsi, Hlm. (sampul belakang). 
4. Saksi atau ahli yang tidak memberikan keterangan atau memberikan keterangan palsu

5. Orang yang memegang rahasia jabatan tidak memberikan keterangan/memberikan keterangan palsu

6. Saksi yang membuka identitas pelapor.

Berbagai modus operandi kejahatan korupsi seringkali sulit untuk diungkap, sehingga dirasa perlu untuk mengkriminalisasi terhadap ketentuan opsional tertentu, misalnya praktik memperkaya diri secara tidak sah (Illicit Enrichment $)^{11}$. Perubahan cara dan perilaku korupsi yang semakin berkembang, membuat diperlukannya terobosan-terobosan dalam penegakan hukumnya.

Penegakan hukum merupakan suatu usaha untuk mewujudkan ide-ide tentang kepastian hukum, kemanfaatan sosial dan keadilan menjadi kenyataan. Proses perwujudan ideide itulah yang merupakan hakikat dari penegakan hukum ${ }^{12}$. Penegakan hukum adalah sebuah tugas. Tugas yang diemban oleh aparat penegak hukum, dan karena tugas, seperti dikatakan Kant, merupakan kewajiban kategoris, kewajiban mutlak, disini tidak mengenal istilah dengan syarat, tugas adalah tugas, wajib dilaksanakan ${ }^{13}$.

Di dalam proses penegakan hukum, ada tiga hal tujuan yang harus diperhatikan, yaitu kepastian hukum, kemanfaatan dan keadilan $^{14}$. Selain kepastian, tujuan hukum berupa keadilan cenderung menjadi isu sensitif yang sangat sering dibicarakan dalam penegakan hukum. M Yahya Harahap mengemukakan jika menegakkan hukum dan keadilan adalah mustahil. Terutama menyangkut dengan keadilan itu sendiri, karena keadilan adalah sesuatu nilai dan rasa yang bersifat nisbi atau relatif, apa yang dianggap adil bagi seseorang atau suatu kelompok, belum tentu dirasakan adil bagi orang lain atau kelompok tertentu, seolah-olah nilai dan rasa keadilan terbatas untuk suatu kelompok dalam suatu batas ruang dan waktu tertentu (for a particular people and particular time and place) ${ }^{15}$.

Saat ini penegakan hukum di Indonesia seolah-olah tersandera dengan dipaksa untuk memperhatikan dan bertitik tolak dari pandangan masing-masing orang yang berkepentingan. Dengan demikian pada setiap langkah penegakan hukum, aparat penegak hukum harus memperhatikan dan berdiri di atas kepentingan anggota masyarakat satu

11 Yusuf, M., (2013), Miskinkan koruptor: Pembuktian Terbalik Solusi Jitu Yang Terabaikan, Jakarta: Pustaka Juanda Tigalima, hlm. 25.

12 Raharjo, S., (2005), Masalah Penegakan Hukum Suatu Tinjauan Sosiologis, Bandung: Sinar Baru, hlm. 24.

13 Tanya, B.L., (2001), Penegakan Hukum dalam Terang Etika, Yogyakarta: Genta Publising, hlm. 35.

14 Mertokusumo, S., (1986), Mengenal Hukum, Yogyakarta: Liberty, hlm. 130.

15 M. Yahya Harahap, (2009), Pembahasan Permasalahan dan Penerapan KUHAP: Penyidikan dan Penuntutan (Edisi Kedua), Jakarta: Sinar Grafika, hlm. 65. 
persatu. Penegakan hukum semacam ini sebenarnya sudah tidak dapat dibenarkan karena lebih mengutamakan kepentingan subjektifitas. Upaya penegakan hukum secara obyektif kadang kalah dengan isu publik yang dikemas dalam pemberitaan informasi yang negatif, sehingga kadang hukum harus dikorbankan demi untuk keadilan dan perikemanusiaan masing-masing orang yang berkepentingan. Begitupula dalam penegakan hukum terhadap tindak pidana korupsi, aparat penegak hukum dituntut untuk senantiasa menyandingkan antara kepastian hukum dengan keadilan.

Telah disebutkan sebelumnya jika semangat pemberantasan tindak pidana korupsi telah terlihat dalam Undang undang Nomor 3 Tahun 1971 tentang Pemberantasan Tindak pidana Korupsi yang memberikan peluang adanya pidana tambahan di luar pidana pokok yang telah ada dalam undangundang tersebut. Secara lengkap pidana tambahan tersebut tercantum dalam Pasal 34 Undang undang Nomor 3 Tahun 1971 tentang Pemberantasan Tindak pidana Korupsi yang berbunyi:

"Selain ketentuan-ketentuan Pidana yang dimaksud dalam KUHP maka sebagai hukuman tambahan adalah:

a. perampasan barang-barang tetap maupun tak tetap yang berwujud dan yang tak berwujud, dengan mana atau mengenai mana tindak pidana itu dilakukan atau yang seluruhnya atau sebagian diperolehnya dengan tindak pidana korupsi itu, begitu pula harga lawan barang-barang yang menggantikan barang-barang itu, baik apakah barang-barang atau harga lawan itu kepunyaan sitem hukum ataupun bukan;

b. Perampasan barang-barang tetap maupun tak tetap yang berwujud dan tak berwujud yang termaksud perusahaan si terhukum, dimana tindak pidana korupsi itu dilakukan begitu pula harga lawan barang-barang yang menggantikan barang-barang itu, baik apakah barangbarang atau harga lawan itu kepunyaan si terhukum ataupun bukan, akan tetapi tindak pidananya bersangkutan dengan barang-barang yang dapat dirampas menurut ketentuan tersebut sub a pasal ini

c. Pembayaran uang pengganti yang jumlahnya sebanyak-banyaknya sama dengan harta-benda yang diperoleh dari korupsi."

Terkait dengan pidana tambahan berupa hukuman membayar uang pengganti sebagaimana diatur dalam Pasal 34 huruf c Undang undang Nomor 3 Tahun 1971 tentang Pemberantasan Tindak pidana Korupsi tersebut, R. Wiyono berpendapat bahwa pelaksanaan pidana tambahan berupa pembayaran uang pengganti hanya terbatas sampai "sebanyak-banyaknya sama" dengan harta yang diperoleh terpidana dari hasil tindak pidana korupsi. Harta benda yang diperoleh dari tindak pidana korupsi jangan hanya ditafsirkan harta yang diperoleh dari hasil tindak pidana korupsi yang masih dikuasai oleh terpidana pada waktu pengadilan menjatuhkan putusannya, tetapi ditafsirkan termasuk pula harta benda yang diperoleh dari hasil tindak pidana korupsi yang pada waktu pengadilan menjatuhkan putusannya, harta benda tersebut oleh 
terdakwa sudah dialihkan penguasannya kepada orang lain ${ }^{16}$.

Namun disayangkan semangat pemberantasan tindak pidana korupsi yang dilakukan dengan pembebanan pidana uang pengganti tidak diikuti dengan jalan keluar yang tegas dalam pasal lain dalam Undang undang Nomor 3 Tahun 1971 tentang Pemberantasan Tindak pidana Korupsi. Hal tersebut hanya diakomodasi dalam penjelasan Pasal 34 Undang undang Nomor 3 Tahun 1971 tentang Pemberantasan Tindak pidana Korupsi yang berbunyi sebagai berikut:

Untuk mendapatkan hasil yang maksimum dari usaha pengembalian kerugian keuangan negara ataupun kekacauan perekonomian negara, maka dianggap perlu sekali atas perampasan barang-barang bukti pada perkara korupsi tidak terbatas pada yang dimaksud dalam Pasal 39 KUHP, sehingga hukuman tambahan itu merupakan perluasan yang diatur dalam KUHP. Apabila pembayaran uang pengganti tidak dapat dipenuhi oleh terdakwa maka berlakulah ketentuan-ketentuan mengenai pelaksanaan pembayaran hukuman denda.

Apabila mengacu pada bunyi penjelasan pasal tersebut di atas dapat diketahui jika terpidana tidak membayar hukuman uang pengganti maka diberlakukan ketentuan mengenai pembayaran hukuman denda, padahal dalam Undang undang Nomor 3 Tahun 1971 tentang Pemberantasan Tindak Pidana Korupsi tidak mengatur tentang pelaksanaan pembayaran denda, sehingga kita harus mengacu pada ketentuan Pasal 30 KUHP terkait denda yang berbunyi sebagai berikut:

1) Pidana denda paling sedikit tiga rupiah tujuh puluh lima sen.

2) Jika pidana denda tidak dibayar, ia diganti dengan pidana kurungan.

3) Lamanya pidana kurungan pengganti paling sedikit satu hari dan paling lama enam bulan.

4) Dalam putusan hakim, lamanya pidana kurungan pengganti ditetapkan demikian; jika pidana dendanya tujuh rupiah lima puluh dua sen atau kurungan, di hitung satu hari; jika lebih dari lima rupiah lima puluh sen, tiaptiap tujuh rupiah lima puluh sen di hitung paling banyak satu hari demikian pula sisanya yang tidak cukup tujuh rupiah lima puluh sen.

5) Jika ada pemberatan pidana denda disebabkan karena perbarengan atau pengulangan, atau karena ketentuan pasal 52, maka pidana kurungan pengganti paling lama delapan bulan.

6) Pidana kurungan pengganti sekalikali tidak boleh lebih dari delapan bulan.

Berdasarkan uraian tersebut telah dapat diketahui jika terpidana tidak membayar pidana tambahan berupa hukuman membayar uang pengganti sesuai ketentuan Undang undang Nomor 3 Tahun 1971 tentang Pemberantasan Tindak Pidana Korupsi maka diganti dengan pidana kurungan maksimal 8 (delapan) bulan. Penyamaan jalan keluar antara pidana denda dengan pidana tambahan berupa pidana uang pengganti tentunya menjadi perdebatan karena pada dasarnya

16 Wiyono, R., (2008), Pembahasan Undang-Undang Pemberantasan Tindak Pidana Korupsi, Jakarta: Sinar Grafika, hlm.142-143. 
pidana denda tidak sama dengan pidana uang pengganti. Pidana denda adalah pidana pokok sedangkan pidana uang pengganti adalah pidana tambahan.

Hal ini jelas berbeda apabila dibandingkan dengan ketentuan mengenai jalan keluar terhadap terpidana yang tidak membayar hukuman uang pengganti dalam Undang undang Nomor 31 Tahun 1999 tentang Pemberantasan Tindak pidana Korupsi yang secara tegas diatur dalam Pasal 18 ayat (2) dan ayat (3) berbunyi sebagai berikut:

2) Jika terpidana tidak membayar uang pengganti sebagaimana dimaksud dalam ayat (1) huruf b paling lama dalam waktu 1 (satu) bulan sesudah putusan pengadilan yang telah memperoleh kekuatan hukum tetap, maka harta bendanya dapat disita oleh jaksa dan dilelang untuk menutupi uang pengganti tersebut.

3) Dalam hal terpidana tidak mempunyai harta benda yang mencukupi untuk membayar uang pengganti sebagaimana dimaksud dalam ayat (1) huruf b, maka dipidana dengan pidana penjara yang lamanya tidak melebihi ancaman maksimum dari pidana pokoknya sesuai dengan ketentuan dalam Undang-undang ini dan lamanya pidana tersebut sudah ditentukan dalam putusan pengadilan.

Persoalan lain muncul ketika upaya eksekusi pidana uang pengganti dalam ketentuan Undang undang Nomor 3 Tahun 1971 tentang Pemberantasan Tindak pidana Korupsi, disaat putusan pengadilan telah mempunyai kekuatan hukum tetap (inkracht van gewijsde). Sebagian besar putusan pengadilan tidak mencantumkan secara tegas dalam diktum putusan terkait bagaimana apabila terpidana tidak membayar hukuman uang pengganti tersebut, sehingga putusan pidana uang pengganti tersebut seolah-olah hanya tulisan yang tidak mempunyai daya ikat eksekutorial apabila tidak dibayar. Padahal apabila konsisten dengan ketentuan penjelasan Pasal 34 Undang undang Nomor 3 Tahun 1971 tentang Pemberantasan Tindak pidana Korupsi seharusnya ada jalan keluar berupa pidana kurungan pengganti, yang seyogyanya lama pidana kurungan pengganti tersebut telah ditulis secara tegas dalam diktum putusan.

Jaksa sebagai pejabat yang diberikan wewenang oleh undang-undang untuk melaksanakan putusan pengadilan yang telah mempunyai kekuatan hukum tetap, akan terhambat tugasnya karena tidak mempunyai jalan keluar untuk mengeksekusi pidana uang pengganti menurut Undang undang Nomor 3 Tahun 1971 tentang Pemberantasan Tindak pidana Korupsi. Hal ini yang kemudian mendorong upaya pemberlakukan isntrumen hukum di bawah undang-undang yang secara konkrit dimanifestasikan dalam bentuk Peraturan Jaksa Agung RI Nomor: PER020/A/JA/07/2014 tentang Petunjuk Pelaksanaan Penyelesaian Uang Pengganti yang Diputus Pengadilan Berdasarkan Undang undang Nomor 3 Tahun 1971 tentang 
Pemberantasan Tindak pidana Korupsi yang diundangkan pada tanggal 13 Agustus 2014.

Berdasarkan Peraturan Jaksa Agung RI ini ada 2 (dua) cara untuk menagih pidana uang pengganti yang tidak dibayar, yaitu cara pertama melalui jalur non litigasi dengan cara negosiasi atau pun musyawarah antara Jaksa Pengacara Negara (JPN) dengan terpidana/ahli warisnya. Selanjutnya cara kedua melalui jalur litigasi dengan melakukan gugatan perdata oleh Jaksa Pengacara Negara (JPN) kepada terpidana/ahli warisnya.

Instrumen hukum ini dilakukan oleh Lembaga Kejaksaan RI selaku Jaksa Pengacara Negara $\quad(\text { JPN })^{17}$ untuk mengupayakan jalan lintas batas dari jalur pidana ke jalur perdata. Secara hierarki ${ }^{18}$ peraturan perundang-undangan tentunya Peraturan Jaksa Agung RI tersebut berada di bawah undang-undang, namun demikian instrumen hukum tersebut telah mampu memberikan ruang gerak bagi Jaksa untuk menuntaskan pekerjaan eksekusi terhadap pidana uang pengganti menurut Undang undang Nomor 3 Tahun 1971 tentang Pemberantasan Tindak pidana Korupsi, serta dapat memulihkan keuangan negara dalam bentuk Penerimaan Negara Bukan Pajak (PNBP).

Penerapan Pidana Uang Pengganti Dalam Penegakan Hukum Pemberantasan Tindak Pidana Korupsi yang Menggunakan Undang undang Nomor 3 Tahun 1971 Tentang Pemberantasan Tindak Pidana Korupsi Pada Masa Mendatang

Pada dasarnya Undang undang Nomor 3 Tahun 1971 Tentang Pemberantasan Tindak Pidana Korupsi telah dinyatakan tidak berlaku sejak tanggal 16 Agustus 1999 berdasarkan ketentuan Pasal 44 Undang undang Nomor 31 Tahun 1999 Tentang Pemberantasan Tindak Pidana Korupsi. Namun demikian untuk perkara korupsi yang dilakukan sebelum Undang undang Nomor 31 Tahun 1999 Tentang Pemberantasan Tindak Pidana Korupsi disahkan dan diundangkan, maka tetap menggunakan ketentuan Undang undang Nomor 3 Tahun 1971 Tentang Pemberantasan Tindak Pidana Korupsi. Hal ini sesuai dengan pemberlakuan asas hukum tidak berlaku surut (non retroaktif) dan asas legalitas guna pemenuhan asas "nullum delictum nulla poena sine praevia lege poenali, yang artinya tidak ada delik, tidak ada pidana tanpa peraturan terlebih dahulu". ${ }^{19}$

17 Berdasakan ketentuan Pasal 30 ayat (2) Undang undang Nomor 16 Tahun 2004 tentang Kejaksaan RI disebutkan bahwa di bidang perdata dan tata usaha negara, kejaksaan dengan kuasa khusus dapat bertindak baik di dalam maupun di luar pengadilan untuk dan atas nama negara atau pemerintah.

18 Berdasarkan penjelasan Pasal 7 ayat (2) Undang undang Nomor 12 Tahun 2011 tentang Pembentukan Peraturan Perundang-undangan, "hierarki" adalah penjenjangan setiap jenis Peraturan Perundang-undangan yang didasarkan pada asas bahwa Peraturan Perundang-undangan yang lebih rendah tidak boleh bertentangan dengan Peraturan Perundang-undangan yang lebih tinggi.

19 Moeljatno, Loc.Cit., hlm.23 
Selanjutnya terkait dengan kewenangan menuntut yang hapus karena daluwarsa dapat dilihat dalam ketentuan Pasal 78 KUHP yaitu:

1) Kewenangan menuntut pidana hapus karena daluwarsa:

1. mengenai semua pelanggaran dan kejahatan yang dilakukan dengan percetakan sesudah satu tahun;

2. mengenai kejahatan yang diancam dengan pidana denda, pidana kurungan, atau pidana penjara paling lama tiga tahun, sesudah enam tahun;

3. mengenai kejahatan yang diancam dengan pidana penjara lebih dari tiga tahun, sesudah dua belas tahun;

4. mengenai kejahatan yang diancam dengan pidana mati atau pidana penjara seumur hidup, sesudah delapan belas tahun.

Di dalam undang-undang tentang

pemberantasan tindak pidana korupsi tidak diatur secara tegas tentang daluwarsa penuntutan sehingga harus kembali kepada ketentuan undang-undang yang lebih umum dalam hal ini adalah KUHP tersebut. Terkait masa daluwarsa dalam perkara korupsi terdapat 2 (dua) pendapat yang berbeda yaitu:

Pendapat pertama, ada pada kasus Miranda melalui Putusan Mahkamah Agung Nomor 545 K/Pid.Sus/2013, Majelis Hakim yang diketuai oleh Dr. Artidjo Alkostar, SH., LLM menyatakan bahwa hakim pada putusan sebelumya yang menyatakan bahwa tindakan Miranda tidak daluwarsa telah benar menerapkan hukumnya. Hal tersebut didasari Article 29 United Nations Conventions Againts Comuption 2003 yang telah diratifikasi UndangUndang Nomor 7 Tahun 2006 tentang
Pengesahan United Nations Convention Againts Corruption, 2003 ("UU 7/2006"): Yang pada intinya karena tindak pidana korupsi adalah kejahatan luar biasa (extra ordinary crime), maka ketentuan Pasal 78 ayat (1) butir ke-2 KUHP dapat disimpangi (judge made law). Pendapat kedua, dapat dilihat pada kasus Toriq Baya'sut, S.H. mantan Kepala Biro Hukum PT SIER (Persero). Tindak pidana yang dilakukan ialah memberi atau menjanjikan sesuatu berupa uang oleh PT SIER (Persero ) kepada seorang pegawai negeri sipil dengan jabatan Kasubdit Kasasi Perdata di Mahkamah Agung Republik Indonesia. Perbutan itu memenuhi unsur dengan maksud menggerakkannya untuk berbuat atau tidak berbuat sesuatu dalam jabatannya yang bertentangan dengan kewajibannya, yang terdapat di Pasal 43A ayat (1) UU 20/2001 jo. Pasal 55 ayat (1) ke-1 KUHP jo. Pasal 64 ayat (1) KUHP. Namun Majelis Hakim pada Pengadilan Negeri Surabaya melalui Putusan Pengadilan Negeri Surabaya Nomor 81/Pid.Sus/2011/PN.SBY berpendapat bahwa dalam kasus ini dakwaan Penuntut Umum tidak dapat diterima sehingga penuntutan terhadap terdakwa Toriq hapus karena telah lewat waktu (daluwarsa). Yang mana kasus itu telah diketahui pada tanggal 30 Juli 1999 sampai dilimpahkannya berkas perkara di Pengadilan Tindak Pidana Korupsi Surabaya pada tanggal 18 Juli 2011 (12 Tahun) sehingga memenuhi unsur daluwarsa di Pasal 78 ayat (1) ke-3 KUHP. ${ }^{20}$

Selanjutnya untuk menghitung masa daluwarsa, menurut Mudzakir pakar hukum acara pidana UII Yogyakarta, dalam

20 Hutomo, Dimas, (2018, Oktober, 05), Daluwarsa Penuntutan Dalam Tindak Pidana Korupsi https://www.hukumonline.com/klinik/detail/lt58e921c313b7b/daluwarsa-penuntutan-dalam-tindak-pidanakorupsi/ diakses terakhir tanggal 27 Mei 2019 pukul 10.18 WIB 
menerapkan Pasal 78 KUHP ini ada dua teori untuk menghitung daluwarsa. Pertama, tindak pidana yang mudah diketahui publik (terbuka), seperti membunuh, membakar rumah, maka daluwarsa dihitung dari perbuatan yang terjadi saat itu. Sedangkan penghitungan daluwarsa yang kedua untuk tindak pidana tersembunyi (terselubung), maka penghitungan sejak diketahui tindak pidana terungkap, sejak itulah dihitung daluwarsa ${ }^{21}$.

Apabila kita merujuk pada pendapat tentang perkara korupsi dapat menyampingkan masa daluwarsa, atau pun perkara korupsi termasuk tindak pidana tersembunyi (terselubung), maka sangat memungkinkan tindak pidana korupsi masa lalu yang dilakukan sebelum Undang undang Nomor 31 Tahun 1999 Tentang Pemberantasan Tindak Pidana Korupsi disahkan dan diundangkan, masih dapat dituntut dan diadili pada masa sekarang dan masa yang akan datang dengan menggunakan Undang undang Nomor 3 Tahun 1971 Tentang Pemberantasan Tindak Pidana Korupsi.

Jika hal ini dilakukan maka aparat penegak hukum harus menyamakan persepsi dan sikap tentang pidana tambahan berupa hukuman membayar uang pengganti. Ketentuan bunyi penjelasan Pasal 34 Undang undang Nomor 3 Tahun 1971 Tentang Pemberantasan Tindak
Pidana Korupsi harus sudah digunakan sejak tahap penuntutan dengan menuliskan secara tegas dalam petitum surat tuntutan tentang besaran pidana uang pengganti, serta mencantumkan subsidiair/dapat diganti dengan pidana kurungan selama berapa lama sesuai dengan ketentuan penjelasan Pasal 34 Undang undang Nomor 3 Tahun 1971 Tentang Pemberantasan Tindak Pidana Korupsi. Hal ini tentunya juga harus diikuti dengan diktum tegas dalam bunyi amar putusan pengadilan tentang besaran pidana uang pengganti, serta mencantumkan subsidiair/dapat diganti dengan pidana kurungan selama berapa lama sesuai dengan ketentuan penjelasan Pasal 34 Undang undang Nomor 3 Tahun 1971 Tentang Pemberantasan Tindak Pidana Korupsi. Langkah tersebut dilakukan agar tidak timbul permasalahan lanjutan tentang pidana uang pengganti, demi terwujudnya sebuah kepastian hukum.

\section{KESIMPULAN}

Kekuatan eksekutorial pidana tambahan berupa hukuman membayar uang pengganti menjadi permasalahan ketika kata "subsidiair/dapat diganti dengan" tidak tertulis secara tegas dalam diktum putusan pengadilan, sehingga uang pengganti yang tidak dibayar kemudian tidak mempunyai jalan keluar. Selanjutnya Kejaksaan RI mengeluarkan istrumen hukum berupa 
Peraturan Jaksa Agung RI Nomor: PER020/A/JA/07/2014 tentang Petunjuk Pelaksanaan Penyelesaian Uang Pengganti yang Diputus Pengadilan Berdasarkan Undang undang Nomor 3 Tahun 1971 tentang Pemberantasan Tindak Pidana Korupsi, memungkinkan negara melalui Jaksa Pengacara Negara (JPN) menagih pidana uang pengganti dengan cara non litigasi atau pun jalur litigasi melalui gugatan perdata.

Adanya pendapat tentang perkara korupsi dapat menyampingkan masa daluwarsa, atau pun perkara korupsi termasuk tindak pidana tersembunyi (terselubung), maka sangat memungkinkan tindak pidana korupsi masa lalu yang dilakukan sebelum Undang undang Nomor 31 Tahun 1999 Tentang Pemberantasan Tindak Pidana Korupsi disahkan dan diundangkan, masih dapat dituntut dan diadili pada masa sekarang dan masa yang akan datang dengan menggunakan ketentuan Undang undang Nomor 3 Tahun 1971 Tentang Pemberantasan Tindak Pidana Korupsi, sehingga aparat penegak hukum harus menyamakan persepsi dan sikap tentang pidana tambahan berupa hukuman membayar uang pengganti dengan menuliskan secara tegas "subsidiair/dapat diganti dengan" dalam surat tuntutan dan putusan pengadilan sesuai dengan bunyi penjelasan Pasal 34 Undang undang Nomor 3 Tahun 1971 Tentang Pemberantasan Tindak Pidana Korupsi.

\section{DAFTAR PUSTAKA}

\section{Buku}

Harahap, M.Y., (2009), Pembahasan Permasalahan dan Penerapan KUHAP: Penyidikan dan Penuntutan (Edisi Kedua), Jakarta: Sinar Grafika.

Kansil, CST., (1989), Pengantar Ilmu Hukum dan Tata Hukum Indonesia, Jakarta: Balai Pustaka.

Koeswadji, H.H., (1994), Korupsi di Indonesia Dari Delik Jabatan Ke Tindak Pidana Korupsi, Bandung: PT Citra Aditya Abadi.

Komisi Pemberantasan Korupsi, (2006), Memahami Untuk Membasmi: Buku Panduan untuk Memahami Tindak Pidana Korupsi, Jakarta: Komisi Pemberantasan Korupsi.

Marzuki, P.M., (2008), Penelitian Hukum, Jakarta: Kencana Prenada Media Group.

Mertokusumo, S. (1986), Mengenal Hukum, Yogyakarta: Liberty.

Moeljatno, (2002), Asas Asas Hukum Pidana. Jakarta: Rineka Cipta.

Prakoso, D., (1986), Kejahatan-Kejahatan yang Merugikan dan Membahayakan Negara, Jakarta: Bina Aksara

Raharjo, S., (2005), Masalah Penegakan Hukum Suatu Tinjauan Sosiologis, Bandung: Sinar Baru.

Tanya, B.L., (2001), Penegakan Hukum dalam Terang Etika, Yogyakarta: Genta Publising.

Wiyono, R., (2008), Pembahasan UndangUndang Pemberantasan Tindak Pidana Korupsi, Jakarta: Sinar Grafika.

Yusuf, M., (2013), Miskinkan koruptor: Pembuktian Terbalik Solusi Jitu Yang Terabaikan, Jakarta: Pustaka Juanda Tigalima. 
202 Yurispruden Volume 2, Nomor 2, Juni 2019, Halaman 189-202

\section{Internet}

Hutomo, D., (2018, Oktober, 05), Daluwarsa Penuntutan Dalam Tindak Pidana Korupsi https://www.hukumonline.com/klinik/d etail/1t58e921c313b7b/daluwarsapenuntutan-dalam-tindak-pidanakorupsi/ diakses terakhir tanggal $27 \mathrm{Mei}$ 2019 pukul 10.18 